\title{
PRE-SERVICE TEACHERS' FEEDBACK ON THEIR EXPERIENCES WHILE ATTENDING THE APPRENTICESHIP PROGRAMME IN KENINGAU
}

\author{
${ }^{1}$ KAMSILAWATI KAMLUN \\ ${ }^{2}$ NIK ZAITUN NIK MOHAMED \\ Pusat Penataran Ilmu dan Bahasa, Universiti Malaysia Sabah, Jalan UMS, \\ 88400 Kota Kinabalu, Sabah \\ 'kamsi@ums.edu.my; 2nzaitun@ums.edu.my \\ Dihantar: 3 Okt 2017 / Diterima: 20 Dis 2018
}

\begin{abstract}
This study explores the pathways followed by the pre-service teacher by collecting their feedback after attending the apprenticeship programme in one of the primary schools in Keningau. The aim is to get an overview of their experiences while attending apprenticeship programme. This study has employed a qualitative approach gathered through classroom observation, reflective journal as well as focus group discussion. The findings of the study depicted that the pre-service teachers' about their experiences are affected by internal and external factors. Internal factors may include inadequacy to teach, attitude problem, mismatch of expectation as well as conflict with the mentor teacher. External factors may include lack of teaching facilities, school community and location of the school. The analyses yielded perspectives which includes several themes: elements of teaching, pre-service-cooperating teachers' interactions related to pedagogy, knowledge of pedagogy, and the acts of teaching.
\end{abstract}

Keywords: Apprenticeship, TESL, teacher training, pre-service teacher, teacher education.

\section{INTRODUCTION}

Bridging theory to practice has always been an issue in the development of teacher professionalism (Dewey, 1938; Wallace 1991; Richards \& Lockhart, 1994, Gutierrez, 1996; Farrel 1998; Loughran, 2002; Tsui, 2003). Therefore, practical teaching has always been associated with many language teaching programs all around the world. This practical training is a fundamental 
period for every beginner teacher. In this paper, however, focuses on the apprenticeship program in one of the primary schools in Keningau specifically on the effectiveness of the programme. It is crucial to get the feedback from the pre-service teachers in order to get an overview of their experiences while attending the apprenticeship program. With experience, pre-service teachers are able to familiarize first hand teaching which force them to be committed their choice of profession (Freemyer, 2008). It is also the phase whereby the pre-service teachers practice what they have acquired and use it for their personal development of what being a teacher is, the knowledge they attained while in the university as well as from other teaching experiences.

There have been cases whereby pre-service teachers could not cope with apprenticeship due to internal and external factors. Internal factors may include inadequacy to teach, attitude problem, and mismatch of expectation as well as conflict with the mentor teacher. External factors may include lack of teaching facilities, school community and location of the school. In addition to these factors, teacher trainees may face problems in their practicum due to their cognition levels that is the comparison between what they have gone through in their schooling days and what they are taught in the university.

\section{RESEARCH OBJECTIVE}

The main objective of this study is to explore the TESL undergraduate's feedbacks on their experiences during the apprenticeship programme based on the following aspects:

1. The pre-service teachers experience in the apprenticeship programme.

2. Based on their observations, reflect on the teaching methods used by the teachers.

3. The extent of the academic training in the TESL Programme help the students during the apprenticeship programme. 


\section{METHODOLOGY}

Qualitative research is the design where this research is being categorized into and it involves four undergraduates from the Faculty of Psychology and Education at a public university in Malaysia, Sabah. Problems that emerged from students' experiences, understanding of the development of pre-service teachers' pedagogical content skills, and relationships during the apprenticeship programme were employed via qualitative research methods. As pointed out by Shank (2002), when it comes to teaching realities, a better understanding of pre-service teachers' socialization has been facilitated by the existing feedback and observation systems in order to allow researchers to have a better understanding regarding the matter. Guba (1990) had brought forward that "realities exist in the form of psychological constructions... [which are] dependent for their form and content on those who hold them" (p. 27). Observations, focused grouping and journal reflections had been included in the data collection methods. The involved pre-service teachers were required to write their journal reflections every day to document their student teaching experiences. At the end of the apprenticeship programme, the involved pre-service teachers were put randomly into focused groups by the researchers. This was done to allow them to share their experiences with their groupmates. This session documented the pre-service teachers' student teaching experiences, which provided 'tools of the trade' for future pre-service teachers.

\section{LITERATURE REVIEW}

The importance of future education in many different aspects in academic professional activity was emphasized by a model named Academic Apprenticeship Education model which was introduced in Finland in 2009. The main aim of the study is to analyse the development of professions in the context of a 1-year Academic Apprenticeship Education model in the field of energy efficiency. Examining the similarities among all the respondents, individuals' networking activity and the process of networking in small groups is a part of what they do. From the results, some changes in the networking ties among all the respondents can be 
seen. However, internal bonds seemed to be created by those small groups of respondent who could communicate. On the other hand, more ties were portrayed at the individual level. From those conclusions, they then proposed a customised educational model that should be created to suit all. By implementing this idea, the quality of education would be much better if the current ad hoc networks were not the only way to organise knowledge exchange among respondents.

A study done by Inceçay (2011) examined the effects of pre-service teachers' language learning beliefs on their practice teaching. Two preservice teachers were chosen randomly to participate in the study (one male, one female). Using a structured interview, field-notes during observations, philosophy statements and journal reflections from the participants, the research employed a qualitative approach. It was revealed by the results of the study that both participants' teachings were influenced by none other than their foreign language learning beliefs. Nevertheless, some discrepancies between the beliefs and practice teaching as depicted by the results were created by some external factors. The findings also showed that the preservice teachers' instructional practices in the aspects of creating language learning environment, roles of teacher and learner within the language classroom and providing learners with necessary strategies are influenced by language learning beliefs especially when they are facing difficulties in the processes. The effected could be related to the pre-service teachers' beliefs on the ideal language learner, ideal language classroom, ideal language teacher, how to overcome these difficulties and difficulties they come across during the language learning process. This finding supports the arguments by Horwitz (1987), Holec (1987), and Puchta (1999) where they stated that individual form their beliefs about language learning as language learners via personal experience. 


\section{FINDINGS}

\section{The pre-service teachers experience in the apprenticeship programme}

When the exposition of the first hand teaching in real classroom situations was implemented by the involved pre-service teachers, some of them experienced culture shock because what they learnt and what they thought about teaching is totally different from what they experience in the real world. The contributors to the culture shock experienced by the pre-service teachers include large classes to teach, limited space for teaching, dealing with student's personal problems as well as dealing with the society. The finding corroborates the idea of shock when the pre-service teachers were faced with realities in public schools during the observation period in the apprenticeship programme. This can be seen in the following comments:

Student 1: I saw the other side of teaching. This morning, we met the teachers and ask if they need help. I have the chance to help one of the teachers. It was a good experience to do something other than teaching.

Student 2: The teacher needs to observe the teachers. Teachers need to have a good observation to know their students. Need to have communication skills.

Student 3: I think, like what they have mentioned, the situation was a bit busy as they have an event in school. I like the bonding between teachers, parents and students. Teachers know the parents, as it is just a small area.

Student 4: I also see a different experience in teaching especially in dealing with students in the rural areas. The teachers are not only involved in teaching the students but also deal with their personal needs as students come from different background. 


\section{Summary}

The apprenticeship programme was aimed to encourage the pre-service teachers to become active participants, inquirers and critical thinkers. The emphasis should be put more on making them reflective thinkers who explore their own teaching styles while accompanied by veteran teachers during their early experiences in the classroom in which the in-service teachers becomes the mentors.

\section{Based on their observations, reflect on the teaching methods used by the teachers}

As shown by the observations of experience in classroom, disappointment could be experienced by the pre-service teachers especially when they do not have good experiences in their first encounters with a real classroom surrounding. Those identified problems are the daily routines and common situations for a significant number of newbie teachers in classrooms. However, the analysis of these problematic situations and the effort in finding solutions to overcome them will almost certainly enable the preservice teachers to work effectively and correctly as well as properly guided by their mentors that later on might be represented in successful teaching experiences. Based on the pre-service teachers' feedback and focus group discussion, the followings are depicted:

Student 1: They did not actually teach during the 3-day period as the syllabuses have ended. The teachers focused on primary 6 students because they are going to form 1 next year. However, my mentor, she made an effort to teach so that we can observe her for 2 times. Most of them are friendly and helpful. She was very committed. When she taught the students, she did it in TPR. All the activities involved physical movement. Teaching aids were pasted on the wall, so they make full use of everything in the classroom.

Student 2: Honestly, teaching in rural areas is more relaxing because of the environment. For their teaching, some teachers inserted games, but most of them use 'chalk and talk', which is the traditional method as they were lacked of facilities. 
Student 3: First teacher: She used big book as she was teaching vowels to standard 1 students. In the activity, she just wrote down the words, and then she asked students to write one word. But the students cannot remember the word. The teacher asks them to draw if they don't remember the word. I think that this is a good method. She gathers students in one row and sits together with the students. Whenever some student loses focus, she will pull them back. Warned the students to get their attention.

Second teacher: He was teaching year 3. There was less interaction with the students during the lesson. Language games were included. He controlled the students with freeze method. The classroom management is good but I think he is too friendly.

Student 4: It is very unique the way the teacher control the class and how she made the student pay attention in class. She brought the teaching aids and it is a good way to capture the students' attention (it was a big and colorful book).

The second teacher used language game. The difference was that the first teacher brings teaching aids. They are really good in classroom control. It is a skill to control the class, as the teacher need to know their students well.

\section{Summary}

The results showed positive feedback of pre-services teachers towards the teaching methods used by some of the in-service teachers. As a result, the pre-service teachers will develop their own image which may differ from their mentor. It also showed the importance of mutual critical views between mentors (in-service teachers) and pre-service teachers. This in some way, will help them to reflect on their own practices by critically observing their mentors.

\section{The extent does of academic training in the TESL Programme help the students during the apprenticeship programme}

Theoretical background doesn't necessary help the students understand the teaching and learning theories behind the pre-service teaching experiences. 
However, they do believe that the academic training in the TESL Programme helps them to equip themselves with the subject knowledge that there are going to deliver to the students during their teaching practice. They also learned on how to handle students in terms of understanding their behaviours and attitudes according to their age. By understanding students' behaviours beforehand, they were able to prepare themselves physically and mentally before entering the classrooms which prevents them from having mental breakdowns when things do not turn out well. The skills and trainings they learned somehow shows them that the reality is so much different when enter the classroom as implied in the following comments:

Student 1: The program that we followed in the university, it kind of, directs us to teach students in urban school. They teach us on how to use ICT. The problem is, a rural area does not have that facility. So when we were there, we were not prepared because we are used to teaching using ICT.

Other than that, the workload is different when teachers are serving in rural school. For instance, they have to guide parents because some of the parents are illiterate.

Student 2: The teachers need to have skills in teaching and preparing teaching aids in rural areas. They need to be flexible and always be ready. In the school, the teachers here had to deal with students from rural area and those staying in the hostel.

Student 3: It is very difficult to use ICT to teach in this school. But the teachers there are creative and some of teacher used whatever they have as teaching materials. I realized that we must have backup plan. Another problem that the teacher faced in this school is that, the students have the tendency to skip school as most of the students live far away from the school.

Student 4: For me, it is very hard to conduct activities in the classroom because the classes in the school are near to each other. It is not conducive and it is very noisy, but the teachers can conduct the lesson really well (probably the teachers are used to the noises). It was not a problem for the teachers to get the students' attention although it was really noisy. This is more to the teachers' skill to manage the classroom. 


\section{Summary}

By reflecting in one's own teaching experiences, the session could contribute to enrich one's experiences in the stage of professional formation. Individual conversations, observations, questioning, mentoring, dialogue, writing to learn are the approaches to reinforce reflection. Teachers' professional development will be developed through this approach because it would allow them to understand the complexities of the realities that could happen in a real world setting and foster a propositional attitude for alternatives of change if needed.

\section{CONCLUSION}

It can be illustrated from the findings that our experience as educators has also postulated that students who are also teachers-to-be embark on their teaching journeys equipped with different pedagogical knowledge, skills and capabilities before engaging in the teaching practice. The knowledge attained by the pre-service teachers is enriched, changed or reinforced by the development of the philosophical background that the university attempts to nurture in students. This means that the purpose of a university program is to 'train' teachers in English teaching as a second language in terms of the language nature and with its dimension in teaching regarding methodology, didactics, pedagogy, etc. When it comes to the procedures and processes to be carried out in a class, pre-service teachers should be allowed to make their own decisions according to their own creativity. For this specific reason, it is considered necessary to enhance reflective skills that allow pre-service teachers to orient their pedagogical interventions on the basis of the specific needs of the environment they are working in. In this case, mentors in schools should facilitate the pedagogical knowledge preservice teachers have constructed during the apprentice of the observations and the articulation of the knowledge provided by the university programs.

\section{Implications for Teacher Education Programs}

The implications for pre-service teachers who teach in teacher preparation programs are that they should be exposed more to the experience of 
teaching realities in real life school settings and suggestions for ways to reduce the shocks during the pre-service teachers teaching period should also be brought forward to them. This could include "the increase of actual teaching opportunities... [and] the time the pre-service teachers observe in schools" (Chepyator-Thomson \& Liu, 2003, p. 4). A suggestion that could be introduced is; observational opportunities can be incorporated into methods, foundation and curriculum courses. 0' Sullivan and Tsangaridou (1992) and Curtner-Smith (1996) stated that the use of early field experiences in literature is considered crucial. Mawer (1995) also suggested that student teachers need experience in teaching before they take another step forward in the real teaching world or they will have apprehension and anxiety in the beginning of their teaching embarkations in schools.

\section{REFERENCES}

Chepyator-Thomson, J. R., \& Liu, W. (2003). Preservice teachers' reflections on student teaching experiences: Lessons learned and suggestions for reform in PETE programs. Physical Educator, 60, 2-12.

Curtner-Smith, M. D. (1996). The impact of an early field experience on preservice physical education teachers' conceptions of teaching. Journal of Teaching in Physical Education, 15, 224-250.

Dewey, J. (1938). Experience and education. New York: Macmillan Publishing House.

Farrel, T. (1998). Reflective teaching the principals and practices. English Teaching. Forum, 36 (4), 10-17.

Freemyer et al. (2008). University school collaboration on mentor training: An evaluation of mentor training programs across Indiana. Paper presented at the Annual Meeting of the American Association of Colleges for Teacher Education, Jan 26, 2006, Retrieved on July 30, 2016 from: http://www. allacademic.com $/$ meta/p35860_index.html

Guba, E. G. (1990). Subjectivity and objectivity. In E. W. Eisner \& A. Peshkin's (Eds.). Qualitative inquiry in education: The continuing debate. (pp. 74-91). New York: Teachers College Press.

Gutierrez, G. (1996). Student foreign language teacher's knowledge growth. In Donald Freeman \& Richards Jack (Eds.). Teacher Learning in Language Teaching (pp. 50-78). Cambridge: Cambridge University Press. 
Holec, H. (1987). The learner as manager: Managing learning or managing to learn. In A. Wenden \& J. Rubin (Eds.). Learner Strategies in Language Learning (pp. 145-157). Englewood Cliffs, New Jersey: Prentice-Hall Inc.

Horwitz, E.K. (1987). Surveying student beliefs about language teaming. In A. Wenden \& J. Robin (Eds.). Learner Strategies in Language Learning. (pp. 119-132). London: Prentice Hall.

Inceçay, G. (2011). Pre-service teachers' language learning beliefs and effects of these beliefs on their practice teaching. Procedia Social and Behavioral Sciences, 15, 128-1.

Loughran, J. (2002). Effective reflective practice. In search of meaning in learning about teaching. Journal of Teacher Education, 53 (1), 33-43.

Mawer, M. (1995). The effective teaching of physical education. New York: Longman.

O’Sullivan, M., \& Tsangaridou, N. (1992). What undergraduate physical education majors learn during a field experience? Research Quarterly for Exercise and Sport, 63 (4), 381-392.

Puchta, H. (1999). Beyond materials, techniques and linguistic analyses: The role of motivation, beliefs and identity. Plenary session at the LATEFL: 33rd International Annual Conference, Edinburgh, pp. 64-72.

Richards, J. \& Lockhart, C. (1994). Reflective teaching in second language classroom. Cambridge: Cambridge University Press.

Shank, G. (2002). Qualitative research. A personal skills approach. New Jersey: Merril Prentice Hall.

Tsui, A.B.M. (2003). Understanding expertise in teaching. Cambridge: Cambridge University Press.

Wallace, M. (1991). Training foreign language teachers. Cambridge: Cambridge University Press. 
